\title{
THE SHARING ECONOMY DILEMMA: THE RESPONSE OF INCUMBENT FIRMS TO THE RISE OF THE SHARING ECONOMY
}

\author{
O DILEMA DA ECONOMIA COMPARTILHADA: A RESPOSTA DAS EMPRESAS \\ ESTABELECIDAS À ASCENSÃO DA ECONOMIA COMPARTILHADA \\ EL DILEMA DE LA ECONOMÍA SOLIDARIA: LA RESPUESTA DE LAS EMPRESAS \\ ESTABLECIDAS AL AUGE DE LA ECONOMÍA SOLIDARIA
}

Raz Godelnik $^{1}$

Cite as - American Psychological Association (APA)

Godelnik, R. (2020, May/Aug.). The sharing economy dilemma: the response of incumbent firms to the rise of the sharing economy. International Journal of Innovation - IJI, São Paulo, 8(2), 176-203.

https://doi.org/10.5585/iji.v8i2.17391.

\begin{abstract}
Objective of the Study: This paper explores whether and to what degree incumbent firms innovate in response to competition from the sharing economy.

Methodology/Approach: Data on incumbents' actions related to the sharing economy between 2011 and 2015 was collected from multiple resources. Two conceptual frameworks, the OECD Oslo Manual and Pisano's Innovation Landscape Map, were jointly used to determine whether incumbents' actions could be considered as innovation and their level of innovativeness.

Originality/Relevance: As the sharing economy has grown rapidly in the last decade, offering new ways to create value, so has the discourse about its disruptive capacity. Yet, not enough is known about the sharing economy's impact on incumbent firms beyond the disruptive capacity narrative.

Main Results: The study identified 187 actions related to the sharing economy that were taken by 134 incumbent firms between 2011 and 2015. Less than half of these actions are considered innovative, and the majority among them are at the lowest end of the innovation continuum.

Theoretical/Methodological Contribution: This study contributes to the literature on the sharing economy by developing a synthesized innovation-based framework to evaluate incumbent firms' response to sharing economy entrants.

Social/management contributions: The results of this study and the methodology it uses provide benchmarking opportunities for incumbents in similar circumstances, and also puts into question the disruptive narrative around the sharing economy.
\end{abstract}

Keywords: Sharing economy. Innovation. Incumbents. Disruptive innovation. Collaborative consumption.

\footnotetext{
${ }^{1}$ Parsons School of Design - The New School, New York, NY - United States. godelnir@newschool.edu
} 


\section{Resumo}

Objetivo do estudo: este artigo explora se e até que ponto as empresas estabelecidas inovam em resposta à competição causada pela economia compartilhada.

Metodologia/Abordagem: os dados sobre as ações das empresas relacionadas com a economia compartilhada entre 2011 e 2015 foram coletados de várias fontes. Duas estruturas conceituais, o Manual de Oslo elaborado pela OCDE e o Mapa do cenário de inovação de Pisano, foram usadas em conjunto para determinar se as ações das empresas estabelecidas poderiam ser consideradas como uma forma de inovação e o seu nível de inovação.

Originalidade/Relevância: assim como a economia compartilhada cresceu rapidamente na última década, oferecendo novas maneiras de criar valor, o mesmo aconteceu com o discurso sobre sua capacidade disruptiva. Entretanto, não se sabe o suficiente sobre o impacto da economia compartilhada nas empresas estabelecidas além da narrativa da capacidade disruptiva.

Principais resultados: o estudo identificou 187 ações relacionadas com a economia compartilhada que foram realizadas por 134 empresas estabelecidas entre 2011 e 2015 . Menos da metade dessas ações são consideradas inovadoras, e a maioria delas está na extremidade inferior do espectro de inovação.

Contribuição teórica/metodológica: este estudo contribui para a literatura sobre economia compartilhada ao desenvolver uma estrutura sintetizada com base na inovação para avaliar a resposta das empresas estabelecidas aos novos participantes da economia compartilhada.

Contribuições sociais/gerencias: os resultados deste estudo e a metodologia usada fornecem oportunidades de benchmarking para empresas em circunstâncias semelhantes, e também questionam a narrativa disruptiva em torno da economia compartilhada.

Palavras-chave: Economia compartilhada. Inovação. Estabelecida. Inovação disruptiva. Consumo colaborativo.

\section{Resumen}

Objetivo del estudio: En este documento se explora si las empresas establecidas innovan en respuesta a la competencia de la economía solidaria, y en qué medida lo hacen.

Metodología/enfoque: Los datos sobre las acciones de las empresas establecidas relacionadas con la economía solidaria entre 2011 y 2015 se recopilaron a partir de múltiples recursos. Se utilizaron conjuntamente dos marcos conceptuales, el Manual de Oslo de la OCDE y el Mapa del panorama de la innovación de Pisano, para determinar si las acciones de las empresas establecidas podían considerarse como innovación y su nivel de innovación.

Originalidad/relevancia: Así como la economía solidaria ha crecido rápidamente en la última década, ofreciendo nuevas formas de crear valor, también lo ha hecho el discurso sobre su capacidad de disrupción. Sin embargo, no se sabe lo suficiente sobre el impacto de la economía solidaria en las empresas establecidas más allá de la narrativa de la capacidad disruptiva.

Resultados principales: En el estudio se identificaron 187 acciones relacionadas con la economía solidaria que fueron adoptadas entre 2011 y 2015 por 134 empresas establecidas. Menos de la mitad de esas acciones se consideran innovadoras, y la mayoría de ellas se encuentran en el extremo inferior del espectro de la innovación.

Contribución teórica/metodológica: Este estudio contribuye a la literatura sobre la economía solidaria mediante la elaboración de un marco sintetizado basado en la innovación para evaluar la respuesta de las empresas establecidas a los nuevos participantes en la economía solidaria. Contribuciones sociales/de gestión: Los resultados de este estudio y la metodología que utiliza proporcionan oportunidades de evaluación comparativa para las empresas establecidas que se encuentran en circunstancias similares, y también pone en tela de juicio la narrativa disruptiva 
en torno a la economía solidaria.

Palabras clave: Economía solidaria. Innovación. Empresas establecidas. Innovación disruptiva. Consumo colaborativo.

\section{Introduction}

Interest in the sharing economy is on the rise. Because this paradigm offers new, effective ways to unlock the value of excess capacity and because it transforms traditional relationships between companies and consumers (Chase, 2015), it is reputed to be a disruptive force (Zhang et al., 2018). At the same time, the sharing economy is quite novel, and little is known about its impact on incumbent firms - i.e., firms which already have a position in the market (Black et al., 2009). It is important to emphasize that although the concept of incumbency as used in this paper does not necessarily imply a strong position in the market, it does consider that incumbents can have "some privileged position in a market relative to new entrants" (Lowes et al., 2016, p. 20).

The goal of this paper is to study the response of incumbents to the sharing economy in terms of innovation, as it is considered an important tool for incumbent firms seeking to create and capture value in the increasingly competitive and volatile business environment they face today (Hagel et al., 2015; Raynor, 2013). I pose the following research questions: How do incumbents respond to the threat of the sharing economy by way of innovation? Can the actions they take be defined as innovation and, if so, what is the nature of the innovation? What types of innovation do incumbents pursue and how innovative are they?

To address these questions, I analyze incumbent firms' actions connected to or influenced by the sharing economy from 2011-2015. I use the frameworks from the OECD Oslo Manual (2005) and Pisano's Innovation Landscape Map (2015) to determine whether these actions can be considered innovative and to what degree. I also categorize them by type of innovation and consider their spatial distribution.

I hope in this paper to illuminate a potential effect of the sharing economy, which could have broad and lasting implications for the overall economy. I provide a framework with which to assess the impact of the sharing economy on incumbents in terms of innovation across different industries and geographies, recognizing that not all innovation is equal. 
Framing the sharing economy and innovation

\section{Sharing economy}

Although the Oxford English and Merriam-Webster dictionaries have published definitions of the sharing economy, there is still much debate about what the sharing economy actually is, starting with the appropriateness of the term itself. Other terms, such as "peer economy," "collaborative economy," "collaborative consumption," and "on-demand economy," are used interchangeably to describe this trend (Roh, 2016). In this paper I have chosen "sharing economy" because it is the most common term for the phenomenon in both popular and academic discourses.

Different scholars emphasize different aspects of the sharing economy. Frenken $\&$ Schor (2017) argue that it is based on sharing underutilized assets, unlocking idle capacity. Schor (2014) sees relationships between strangers as the key difference between the sharing economy and similar trends of the past. Thus, she calls the phenomenon "stranger sharing." Schor also points to another novel dimension, the use of digital platforms, which can reduce the costs and risks involved in transacting with strangers. Belk (2014) focuses on temporary access to goods and services and reliance on the Internet, especially Web 2.0 technologies. Sundararajan (2016) offers five characteristics identifying the sharing economy: It is largely market-based, puts underutilized capital to use, relies on crowd-based networks, and blurs lines between the personal and the professional and between fully employed and casual labor.

The scope of the sharing economy is also debated, with some authors suggesting broad boundaries and others narrow ones (Acquier et al., 2017). In some cases, the sharing economy is defined narrowly but as part of a larger ecosystem, including various forms of collaborative, platform-based activity (Frenken \& Schor, 2017). While a narrow scope may offer some advantages (Acquier et al., 2017), a broad scope can reflect the breadth of the sharing economy and is therefore a good fit for an exploratory study such as mine. I thus use Frenken et al.'s (2015) broader framework, which includes four categories: consumer-to-consumer (C2C) platforms providing temporary access to physical goods, $\mathrm{C} 2 \mathrm{C}$ secondhand markets, $\mathrm{C} 2 \mathrm{C}$ ondemand service platforms, and business-to-consumer (B2C) product-service platforms.

Services such as Airbnb, Uber, and Lyft have created successful business models using key sharing economy elements such as peer-to-peer exchanges, digital platforms, a shift from ownership to access, the use of excess capacity, and the creation of trust between strangers. These and other examples have helped to shape the narrative of the sharing economy mainly in terms of a Schumpeterian process of creative destruction, in which new business models disrupt 
or are about to disrupt incumbent companies and transform industries (Belk, 2014; Laurell \& Sandström, 2016; Mair \& Reischauer, 2017; C. J. Martin, 2016). Beyond this somewhat simplistic narrative, debate is ongoing about diverse societal, environmental, and economic impacts of the sharing economy (e.g., Frenken, 2017; Murillo et al., 2017; Schor, 2014; Schor \& Attwood-Charles, 2017).

But while many topics have been discussed, the impact of the sharing economy on incumbents has been explored less often. Only a handful of empirical studies have examined the effects of sharing economy entrants on current industries. These include research on the impact of Airbnb on U.S. hotel markets (Dogru et al., 2019), the influence of San Francisco's CarShare program on travel demand and car ownership (Cervero et al., 2007), the effects of car sharing on household vehicle holdings in North America (E. Martin et al., 2010), and the impact of Craigslist on local newspapers (Seamans \& Zhu, 2014). These studies find that, in general, the sharing economy has a negative economic impact on incumbents.

But other evidence is mixed. On the one hand, a 2017 report analyzing 13 global market suggested hotels continue to show strong performance results despite Airbnb's growing popularity (Haywood et al., 2017). On the other hand, taxi medallion prices in major U.S. cities have fallen significantly over the last couple of years (Bagchi, 2018). This suggests that although sharing economy companies such as Uber and Lyft may be undermining incumbent taxi businesses, the traditional hospitality industry has less to fear from Airbnb and its peers.

Others (Belk, 2014; Ciulli \& Kolk, 2019; Matzler et al., 2015; Owyang, 2015a; Owyang \& Samuel, 2015; Roma et al., 2019; Zhang et al., 2018) have explored various emerging strategies of incumbents in response to the sharing economy, as well as incumbents' involvement with the sharing economy. Nevertheless, there is still a gap in our understanding of this relationship, which this study aims to fill.

The sharing economy has quickly expanded to a wide range of industries (Zhang et al., 2018). Botsman (2014) suggests that any industry where one finds complex experiences, broken trust, redundant intermediaries, or limited access is a good fit for sharing economy solutions. According to a 2015 database of 865 sharing economy companies created by JustPark, the most popular industry categories globally are transport (127 companies) and travel (111). In terms of geographic distribution, almost half of the companies involved operate in the U.S. (422), followed by the U.K. (88), France (40), Canada (28), India (28), Australia (23), Spain (23), Germany (20), the Netherlands (15), and Italy (14). In developing countries, limited Internet connectivity and relatively poor access to mobile payment systems may be barriers to the 
development of the sharing economy. Moreover, informal sharing services are already common in many developing countries, which may reduce the incentive to take advantage of sharing economy platforms (Jehlička \& Daněk, 2017).

\section{Framing innovation}

The existing literature provides numerous definitions of innovation, each emphasizing different dimensions of the phenomenon. Schumpeter (1934) distinguishes among five different types of innovation: new products, new methods of production, opening new markets, new sources of supply, and new forms of business organization. Some researchers define innovation through the lens of implementation. Over time, the focus has shifted from the production of ideas to their implementation (Amabile, 1988; Van de Ven, 1986).

However, understanding innovation requires more than just a definition or even an innovation typology, either of which can itself be challenging to create (Garcia \& Cantalone, 2002). It also requires clarity about the business context because companies do not innovate in isolation (Dahlander \& Gann, 2010; Edquist, 2006). The relevant context in this study is the emergence of the sharing economy as a potential game changer for business. We can better understand the progress and potential impact of this economy by considering three key frameworks of innovation that have evolved over the last decades: disruptive innovation, open innovation, and systems of innovation.

Disruptive innovation emerged from the seminal works of Christensen (1997) on the demand-side theory of disruption and Henderson and Clark (1990) on the supply-side theory of disruption. Christensen looked at the ways in which entrants could successfully challenge incumbents by offering simpler, cheaper, and more convenient versions of existing products and services. At first, these appeal to new or less-demanding customers. In time, they improve until they meet the needs of more demanding customers (Christensen et al., 2015). Henderson and Clark developed the concept of architectural innovation-a change in how product components are assembled rather than in the components themselves. The Henderson-Clark theory distinguishes between components knowledge and architectural knowledge, suggesting that while incumbent firms are good at developing new components (component knowledge), they have trouble finding new ways to put these components together (architectural knowledge) (Gans, 2016).

The framework of disruptive innovation supports our understanding of the competitive dynamics between entrants and incumbent firms. It also offers explanations for the difficulties 
incumbents face in responding to new threats and suggestions for how to deal with them (e.g., Charitou \& Markides, 2003; Christensen \& Raynor, 2003; Hagel et al., 2015). But as critics suggest (e.g., Downes \& Nunes, 2013; Moazed \& Johnson, 2016; Wadhwa, 2015), disruptive innovation, as a firm-focused framework, does not adapt easily to a changing business, technological, and economic landscape. If we are to make sense of innovation within a context of large-scale changes - ones that challenge twentieth-century fundamentals such as an emphasis on scientific management, scale, and productivity (Gorbis, 2013) -we need a better understanding of the environment in which firms operate and of relationships between firms and other players in that environment, not just of the firms themselves.

A newer framework, open innovation, is more attentive to the changing business environment. Defined as "the use of purposive inflows and outflows of knowledge to accelerate internal innovation, and expand the markets for external use of innovation, respectively" (Chesbrough, 2006, p. 1), open innovation manifests the transition from knowledge stocks to knowledge flows, reflecting the rapidly decreasing value of distinctive stocks of knowledge, on which companies relied for decades (Hagel \& Brown, 2011).

Open innovation acknowledges the limits of scale in business and the related principle of Joy's law: "No matter who you are, most of the smartest people work for someone else" (McKinnon, 2015). In response, open innovation offers a paradigm shift from a closed model, where R\&D culture is inwardly focused, to an open model, where "projects can be launched from either internal or external technology sources and new technology can enter into the process at various stages" (Chesbrough, 2006, p. 4). A firm could be engaged in different modes of knowledge flows - outside-in (inbound), inside-out (outbound), and two-way interaction with external actors (coupled). However, as West and Bogers (2013) point out, identifying and acquiring knowledge from external resources is only one part of the open-innovation process. The two others are integration and commercialization, requiring assimilation of new knowledge with the firm's R\&D culture and alignment with its business model, respectively.

Overall, the effectiveness of open innovation seems to depend greatly on companies' relationships with external actors, as well as their ability to create "a culture that values outside competence and know-how" (Gassmann et al., 2010). Both of these factors suggest that we need a more systemic approach to innovation. Innovation is more than just transforming inputs to outputs; we need to account for the many factors involved in maximizing the effectiveness of the innovation process. Termed 'systems of innovation' (SI), this approach highlights the systemic and interdependent nature of innovation: “A firm's innovative capability is affected 
by what it produces (its sector), by where it produces (its localization), by how it produces and with whom it interacts (its institutional environment)" (Johnson \& Lehmann, 2006, pp. 3-4).

Defined by Edquist (1997) as "all important economic, social, political, organizational, institutional and other factors that influence the development, diffusion, and use of innovations" (p. 14), SI addresses both product (new or better products and services) and process innovation (new ways of creating products and services) (Edquist, 2006). SI emphasizes network formation and interaction at different scales-national (Lundvall, 1985), regional (Boekema, Morgan, Bakkers, \& Rutten, 2000), and technological/sectoral (Carlsson \& Stankiewicz, 1991). These scales could be thought of as complementary or as variants of a generic SI approach (Edquist, 1997).

As Johnson and Lehmann (2006) suggest, perhaps the most basic aspect of SI is that it is "interactionist." It is also, therefore, "systemic." Again, companies do not innovate in isolation, "but in collaboration and interdependence with other organizations" (Edquist, 2006, p. 2). Institutions also shape systems: "Sets of common habits, norms, routines, established practices, rules, or laws that regulate the relations and the interactions between individuals, organizations and groups. They are the rules of the game" (Edquist, 2006, p. 2).

Built on theories of interactive learning and on evolutionary theories of innovation (Edquist, 2000), SI provides a richer context for understanding the innovation process at every level. Focusing on the sectoral level, for example, Malerba offers five main elements that should be explored in order to fully understand the innovation processes and dynamics of any particular sector: knowledge, technologies, actors, networks, and institutions (Al-Saleh, 2010). This framework not only accounts for the complexity and interdependency of systems, but it also shifts away from traditional economic thinking, which focuses mainly on understanding structure and competition in a stable environment (Al-Saleh, 2010).

The growing complexity of the innovation process-where linear cause-effect relationships are becoming a thing of the past, and interdependent and nonlinear relationships shape the innovation processes - is most amenable to evaluation using an open and systemic framework. I therefore draw on that framework in my assessment of the incumbent firms' responses to the sharing economy. For purposes of this study, I rely primarily on two frames of reference that apply a more open, systemic approach to innovation: the OECD Oslo Manual (2005) and Pisano's (2015) Innovation Landscape Map.

The OECD Oslo Manual is considered the primary international guideline for defining and assessing innovation activities, enabling analysis and comparison of data from across the 
world. It has been used to describe innovation at the firm level (Gunday et al., 2011). Its minimum requirement that an innovation would be new to the firm, not to the sector or the world, enables me to focus on changes at the firm level. The manual also stipulates that "innovation does not need to be developed by the firm itself but can be acquired from other firms or institutions through the process of diffusion" (OECD, 2005, p. 17), manifesting the open and systemic approach that I adopt in this study. The latest edition of the manual, which is used for the study, defines innovation as "the implementation of a new or significantly improved product (good or service), or process, a new marketing method, or a new organizational method in business practices, workplace organization or external relations" (OECD, 2005, p. 46).

This study aims to assess the degree of innovativeness of the incumbents' actions identified as "innovation" from the firm's perspective. Thus, what matters is whether actions produce outcomes new to the firm, not whether firms demonstrate a more universal capacity or propensity to innovate (Gunday et al., 2011). Pisano's Innovation Landscape Map is especially useful for this purpose.

Using technological and business-model changes as variables, Pisano (2015) presents a multidimensional scale of innovativeness, extending from low (routine) to high (architectural). These variables provide a broader innovativeness framework than one bounded by marketing and technological discontinuities only (Garcia \& Cantalone, 2002), which is oriented exclusively toward product innovation. Pisano's map also frames innovation in terms of business strategy; it is a tool for guiding real-world decisions, not for evaluating economic trends. Thus, it is especially useful in assessing incumbents' choices in response to the sharing economy.

\section{Data and methods}

I use the following three-step method to analyze incumbent firms' responses to the sharing economy:

Step 1: Collecting data on actions taken by incumbent firms that could be connected to or influenced by the sharing economy.

Step 2: Analyzing data using the OECD Oslo Manual (2005) to determine which actions identified in Step 1 could be considered innovative and categorize their type (product, process, marketing, organizational). 
Step 3: Assessing the innovativeness of the actions identified in Step 2, using Pisano's (2015) Innovation Landscape Map.

\section{Step 1: Data collection}

I constructed the database for this study by identifying news stories about incumbent firms' activity related to the sharing economy, either directly (i.e., collaboration with, investment in, or acquisition of a sharing economy company) or indirectly (i.e., any action that could be associated with sharing economy activities).

To assemble the stories, I initially searched the LexisNexis database using the search terms "sharing economy," "collaborative economy," "collaborative consumption," and "ondemand economy" for the period 2011-2015. As the results were limited, I conducted an additional search using the following resources:

1. Four leading online business, technology, and sustainability news websites (Fast Company, TechCrunch, TriplePundit, and GreenBiz) that had published multiple stories on the sharing economy were identified and searched using the same search terms used for LexisNexis.

2. Dedicated sharing economy resources such as Sharable, the Collaborative Economy Library, and Owyang's database of large brands' activities in the collaborative economy (Owyang, 2015a) were manually searched for relevant news stories.

3. Websites of sharing economy companies listed in the report "Sharing Economy: An In-Depth Look at Its Evolution \& Trajectory Across Industries” (Olson \& Kemp, 2015) were manually searched for stories on relationships with incumbent firms.

All of the collected news stories were then screened to identify news stories describing an action taken by an incumbent firm in relation to the sharing economy, as the latter is defined by Frenken et al.'s (2015) four categories. All stories that passed the screening were then included in the database for this study, which covers the period 2011-2015.

Searching profile pages from Wikipedia, the business social network sites LinkedIn and Glassdoor, and other public resources such as companies' financial reports, I added information on each of the incumbent firms included in the database. It included number of employees, annual revenues, corporate type (private or public), location of headquarters, and year of founding. 
Finally, I determined the geographical location (country and region) of each action. Usually this is the country where the incumbent firm is headquartered. In cases where the action took place in another country, that country was coded. For example, if the American company Ford starts a car-sharing service in Germany, the activity is categorized as taking place there. It should be noted that the data collected in Step 1 was limited to English-language resources only, which may limit the scope of this study.

\section{Step 2: Identifying innovation}

I first categorized all actions identified in Step 1 according to the OECD Oslo Manual's (2005) definitions of action types:

1. Innovation: "the implementation of a new or significantly improved product (good or service), or process, a new marketing method, or a new organizational method in business practices, workplace organization or external relations" (p. 46).

2. Innovation activities: "all scientific, technological, organizational, financial and commercial steps which actually, or are intended to, lead to the implementation of innovations" (p. 47).

3. Non-innovation: actions that do not meet the above criteria.

I created additional rules, in the spirit of the manual, to help reach accurate classifications:

1. Non-continuous activities, such as one-day campaigns, are categorized as noninnovation.

2. Pilot projects and tests that could evolve into fully implemented innovations are categorized as innovation activity.

3. Investment in sharing economy companies, along with mergers and acquisitions involving them, are categorized as innovation activity. The manual states as follows: "Mergers with, or the acquisition of, other firms are not considered organizational innovations, even if a firm merges with or acquires other firms for the first time" (p. 52). However, these activities could lead to the implementation of innovations.

Next, I analyzed all actions under the "innovation" category to identify their type, per 
the manual's four options:

1. Product innovation: "Introduction of a good or service that is new or significantly improved with respect to its characteristics or intended uses. This includes significant improvements in technical specifications, components and materials, incorporated software, user friendliness, or other functional characteristics" (p. 48).

2. "Process innovation: Implementation of a new or significantly improved production or delivery method. This includes significant changes in techniques, equipment, and software" (p. 49).

3. Marketing innovation: "Implementation of a new marketing method involving significant changes in product design or packaging, product placement, product promotion, or pricing" (p. 49).

4. Organizational innovation: "Implementation of a new organizational method in the firm's business practices, workplace organisation or external relations" (p. 51).

\section{Step 3: Determining level of innovativeness}

Step 3 uses Pisano's Innovation Landscape Map to assess the innovativeness of actions categorized as innovative in Step 2. While Step 2 takes an economic approach to the innovation process, Step 3 offers a strategic perspective.

Pisano’s (2015) map encompasses four innovation categories:

1. Routine innovation: Novel changes that are built on the company's existing technological competences and fit with its existing business model.

2. Disruptive innovation: Novel changes that necessitate a new business model but not new technical competences.

3. Radical innovation: Novel changes that require new technical competences but not a new business model.

4. Architectural innovation: Novel changes that demand both new technical competencies and a new business model.

\section{Results}

Between 2011 and 2015, 134 incumbent firms took 187 actions that could be associated with the sharing economy, per the definitions used in this study (see Table 1 for year-by-year 
data; see supplementary materials for the full dataset). These incumbents are mostly large companies as measured by number of employees and by revenues, two common metrics of organization size (Mabert et al., 2003). Eighty-three of the companies (62\% of the total) have more than 10,000 employees, and $89(66 \%)$ have annual revenues of more than $\$ 1$ billion. Only a handful of the incumbent firms could be considered small and medium-sized enterprises (SMEs): 17 companies (13\%) on the list have fewer than 500 employees and 4 companies (3\%) have annual revenues less than $\$ 50$ million. One hundred and three companies (77\%) are public and $31(23 \%)$ are privately held. Thirty-three are subsidiaries of a parent company. Most companies are relatively old, with only twenty founded after 2000. Half of the latter have fewer than 500 employees.

The 187 actions are spread unevenly across North America, Europe, and Australia. The overwhelming majority of actions took place in the U.S. (140 actions), followed by the U.K. (10), Germany (9), Australia (8), and ten other countries with three or fewer actions each (see Figure 1).

Of the actions, 145 (78\%) involve some type of relationship between the incumbent and a sharing economy company, including investment, strategic partnerships, and collaborative marketing campaigns. Of these 145 actions, 21 (14\%) were investments in a sharing economy platform (for example, Wyndham investing in home-swapping startup LoveHomeSwap), 82 (57\%) were non-strategic relationships (for example, TireBuyer partnering with Lyft to offer discounts to frequent drivers), and 42 (29\%) were strategic or potentially strategic relationships (for example, Starbucks partnering with Postmates to offer a drink-delivery service). Three companies (Uber, Lyft, and Airbnb) are involved in 52 of these 145 actions (26, 16, and 10 actions, respectively). In the other 42 cases (22\%), incumbents operated on their own (e.g., Volkswagen launched a car sharing program, and Hyatt Union Square, in New York, launched a rental program for items such as jewelry and home appliances).

Table 1 - Actions taken by incumbent firms that could be associated with the sharing economy

\begin{tabular}{|c|c|c|}
\hline Year & No. of actions & Percentage \\
\hline 2011 & 9 & 5 \\
\hline 2012 & 17 & 9 \\
\hline 2013 & 53 & 28 \\
\hline 2014 & 39 & 21 \\
\hline 2015 & 69 & 37 \\
\hline
\end{tabular}

Source: Author's database. 
In Step 2, I categorized the 187 actions according to my modified version of the manual's definitions (see Table 2). The "innovation" category is the leading one among the three, with over 40 percent of the total number of actions (e.g., W Hotels partners with Desks Near Me to provide collaborative workspaces in its Manhattan Hotels), followed closely by the "noninnovation" category (e.g., Home Depot partnering with Uber to offer its customers a delivery of Christmas trees, a non-continuous activity). The third category, "innovation activity," is far behind the first two, with only about fifth of the total number of actions (e.g., Enterprise holdings acquires rideshare startup Zimride - M\&A activities are categorized as innovation activity in accordance with the manual).

Table 2 - Actions included in the database according to the OECD Oslo Manual

\begin{tabular}{|c|c|c|}
\hline Category & No. of actions & Percentage \\
\hline Innovation & 78 & 42 \\
\hline Innovation activity & 39 & 21 \\
\hline Non-innovation & 70 & 37 \\
\hline
\end{tabular}

Source: Author's database.

Figure 1 - Geographical spread of the different types of actions taken by incumbent companies

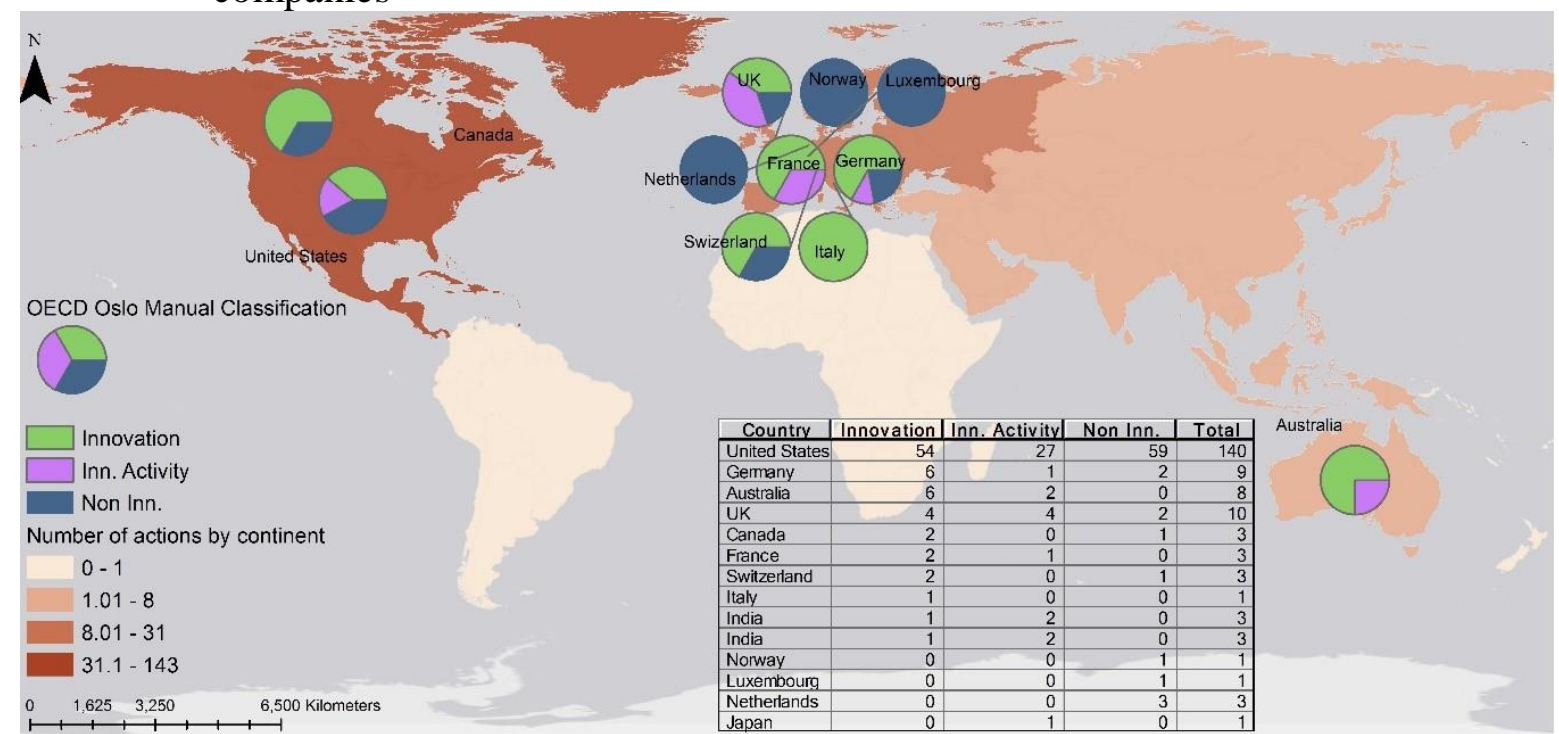

Source: Author's database.

The majority of the 78 actions categorized as innovation took place in North America (72\%), followed by Europe (19\%), Australia (8\%), and Asia (1\%) (see Figure 1).

These 78 innovative actions were taken by 66 companies. One, BMW, is involved in 
three actions. Twelve-Amazon, B\&Q, Citibank, Ikea, Hyatt, Ford, Intuit, Levi Strauss, Patagonia, Swisscom, West Elm, and Westin Hotels-took two actions each. Most of the 66 companies involved with innovation (59\%) have more 10,000 employees. SMEs are overrepresented among innovative companies. Just $13 \%$ of companies in the dataset are SMEs, but $18 \%$ of companies involved in innovation are SMEs. In line with the overall dataset, $76 \%$ of the companies taking action were public and $24 \%$ were privately held. Young companies are also overrepresented among active firms. While only $15 \%$ of companies in the dataset were founded after 2000, $20 \%$ of companies taking innovative actions were launched in the new millennium.

Geographically, innovative actions were concentrated in North America-72\% of the companies involved in "innovation" are located in the North America (mostly in the U.S.), 19\% in Europe (mostly in Germany and the U.K.), $8 \%$ in Australia, and 1\% in Asia. The geographic spread is similar to that of the whole database, with the U.S. (-4\%) and Asia (-2\%) losing some share to Europe (+2\%) and Australia (+4\%) (see Figure 2). Most of the innovations (62) took place from 2013-2015, with 2015 being the most innovative year (23 innovations). As a share of overall activity, the number of innovations fell from $89 \%$ in 2011 to only $33 \%$ in 2015.

Figure 2 - Comparison of the geographical spread of incumbent companies in Steps 1 (actions) and 2 (innovations)

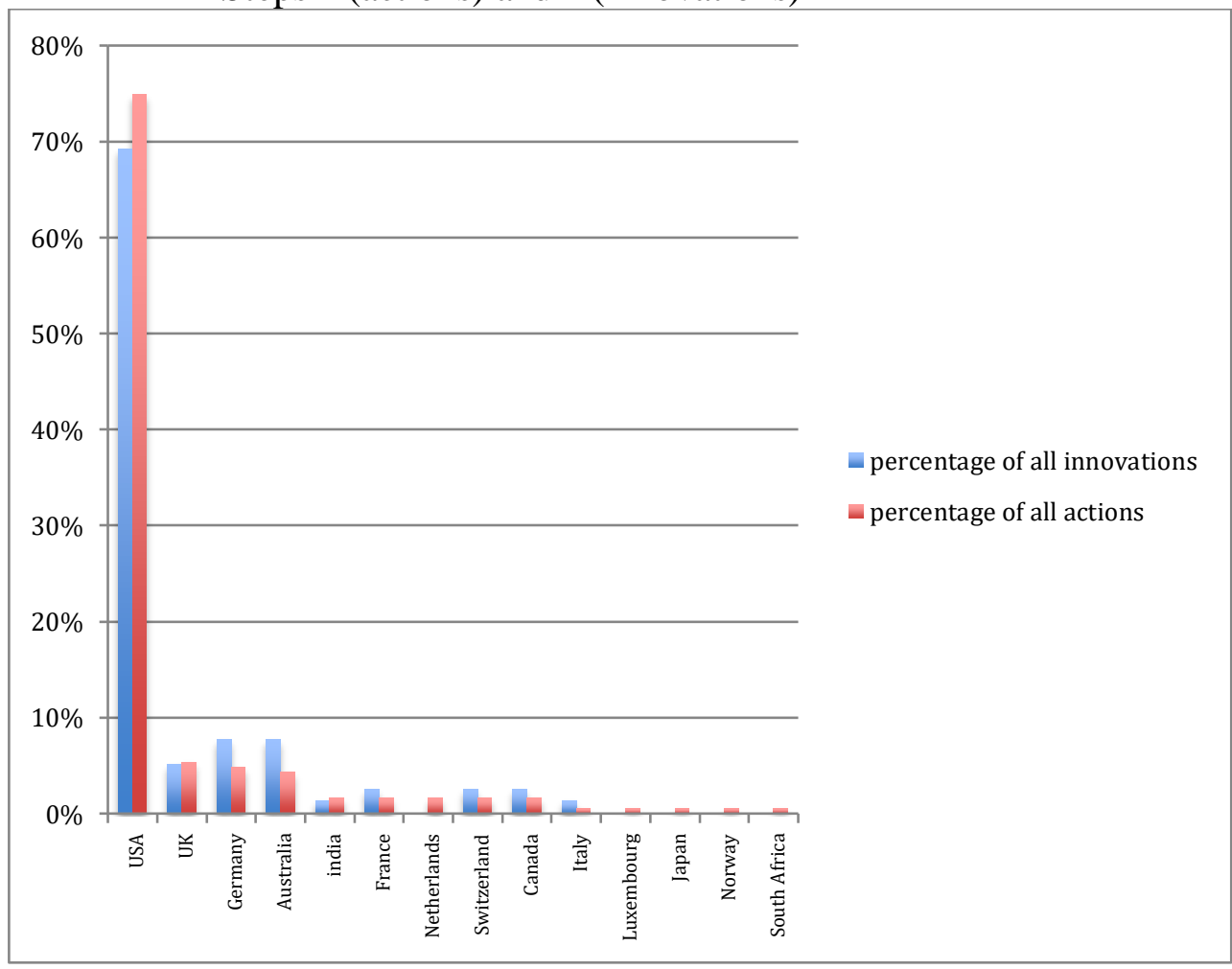

Source: Author's database. 
Firms in 17 industries were involved in the 78 innovative actions (see Table 3). Four of these industries were involved in half of them-retail (13), hospitality (10), auto and transportation (10), and finance (7).

Table 3 - Innovation actions by industry

\begin{tabular}{|l|c|c|}
\hline \multicolumn{1}{|c|}{ Industry } & No. of actions & Percentage \\
\hline Retail & 13 & 17 \\
\hline Hospitality & 10 & 13 \\
\hline Auto \& transportation & 10 & 9 \\
\hline Finance & 7 & 8 \\
\hline Business services & 6 & 8 \\
\hline Apparel \& accessories & 6 & 8 \\
\hline Restaurants & 6 & 5 \\
\hline Information technology & 4 & 5 \\
\hline Insurance & 4 & 4 \\
\hline Telecommunications & 3 & 3 \\
\hline Real estate & 2 & 1 \\
\hline Online services & 2 & 1 \\
\hline Media & 1 & 1 \\
\hline $\begin{array}{l}\text { Arts, entertainment \& } \\
\text { recreation }\end{array}$ & 1 & 1 \\
\hline Energy & 1 & 1 \\
\hline Manufacturing & 1 & 3 \\
\hline Airlines/aviation & 1 & 3 \\
\hline
\end{tabular}

Source: Author's database.

Most of the innovation is in products (66\%). Product and marketing innovations together account for $86 \%$ of the innovations identified (see Figure 3). 
Figure 3 - Innovations categorized according to the OECD Oslo Manual's innovation typology

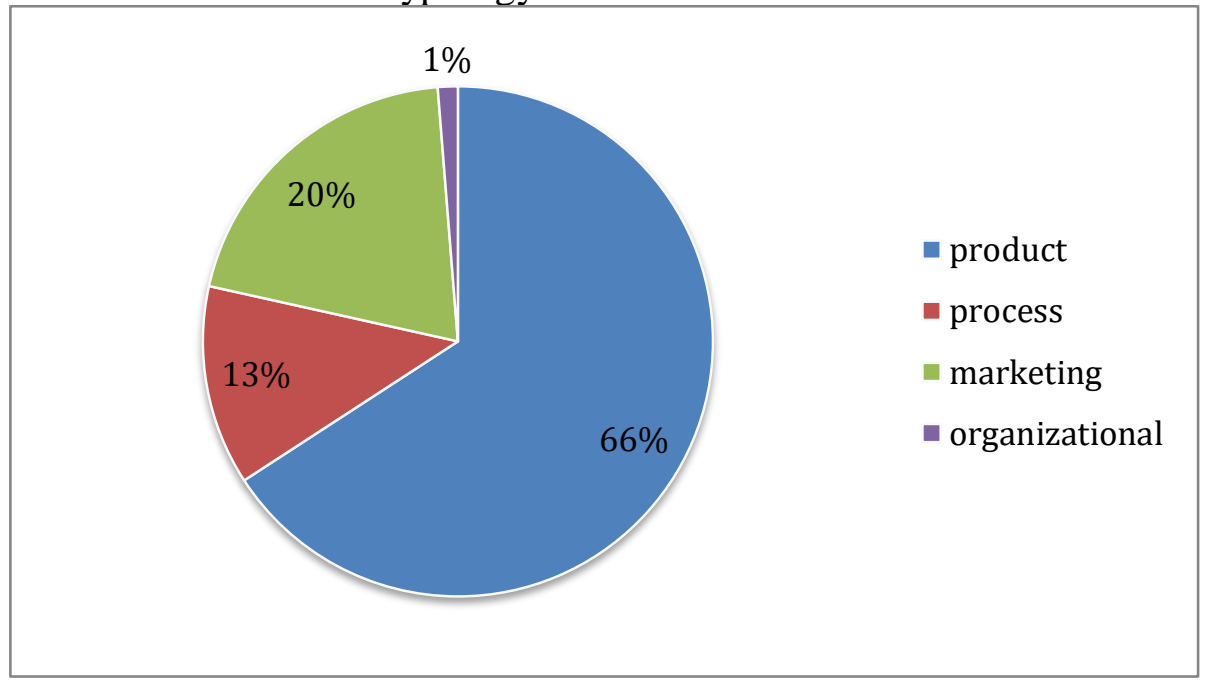

Source: Author's database.

The overwhelming majority (91\%) of the 78 innovations were routine (see Table 4); e.g., SAP launches a carpooling application called TwoGo, or Citibank sponsors a New York City bike sharing program (in both cases the innovation builds on the company's existing technological competences and fits with its existing business model). Just 7 innovations (9\%) were disruptive; e.g., Toyota offers a new rental program at its dealerships or EasyJet Airlines launches a peer-to-peer car rental service (in both cases it is a novel change requiring a new business model but not new technical competences). None of the actions were radical or architectural.

The companies introducing disruptive innovations are Volkswagen, Toyota, Ford, B\&Q, EasyJet Airlines, BMW (twice), and Sixt (with BMW). Companies in the auto/transportation industry are responsible for more than two thirds of the disruptive innovations (see Table 5). The geographical spread of the innovations shows that the majority of the disruptive ones (86\%) took place in Europe (mostly in Germany). Only 14\% took place in the U.S. 
Table 4 - Innovation actions categorized according to Pisano's Innovation Landscape Map

\begin{tabular}{|l|c|c|}
\hline Innovation type & No. of actions & Percentage \\
\hline Routine & 71 & 91 \\
\hline Disruptive & 7 & 9 \\
\hline Radical & - & - \\
\hline Architectural & - & - \\
\hline
\end{tabular}

Source: Author's database.

Table 5 - Innovation actions categorized according to Pisano's Innovation Landscape Map by industry

\begin{tabular}{|l|l|l|l|}
\hline \multicolumn{1}{|c|}{ Industry } & Routine & Disruptive & Radical \\
\hline Retail & 12 & 1 & - \\
\hline Auto \& transportation & 5 & 5 & - \\
\hline Hospitality & 10 & - & - \\
\hline Information technology & 4 & - & - \\
\hline Finance & 7 & - & - \\
\hline Restaurants & 6 & - & - \\
\hline Business services & 6 & - & - \\
\hline Insurance & 4 & - & - \\
\hline Apparel \& accessories & 6 & - & - \\
\hline Telecommunications & 3 & - & - \\
\hline Real estate & 2 & - & - \\
\hline Media & 1 & - & - \\
\hline Airlines/Aviation & - & 1 & - \\
\hline Arts, Entertainment \& & 1 & - & - \\
Recreation & & - & - \\
\hline Online services & 2 & - & - \\
\hline Energy & 1 & - & - \\
\hline Food \& beverage & - & - & - \\
\hline Consumer goods & - & - & - \\
\hline Logistics & - & - & - \\
\hline Hospital \& Health Care & - & - & \\
\hline Cosmetics & - & & \\
\hline Manufacturing & 1 & - & - \\
\hline
\end{tabular}

Source: Author's database.

\section{Discussion}

The results suggest that incumbent firms have been relatively timid in developing innovative responses to the sharing economy. Only $42 \%$ of actions identified in the study are categorized as innovative, and among them more than $90 \%$ are placed at the lowest end of the innovation continuum. 
These findings may surprise observers following the sharing economy through popular media, where claims to the effect that "certain industries have to rewire themselves, or prepare to sink into the quicksand of the past" (Sacks, 2011) have become more common. In addition, marketing and consulting firms keep reminding incumbents that "where a consumption model has prevailed in a sector for many years, it is often most at risk of disruption" (PwC, 2015a, p. 28). One often hears warnings like the following: "if you're not yet feeling the effects of collaborative consumption, it's only a matter of time" (Owyang, 2015b).

This sort of language fosters a narrative in which the sharing economy is seen as disruptive and in which incumbent firms that do not respond to it are putting themselves at a disadvantage. However, my findings show that most incumbents do not buy into this narrative. Only 134 of them were identified in this study as taking some sort of action in response to the sharing economy (innovation, innovation activity, or non-innovation). Those that took action did so in a cautious manner.

One possible explanation for the gap between reality and the disruption narrative is that incumbent firms take this narrative with a grain of salt. Incumbents may recognize that there is still a relatively limited demand for sharing economy services beyond those offered by a handful of media darlings such as Uber and Airbnb. As Lacy puts it, "without Uber, the sharing economy would be an economy like Greece is an economy" (2015).

An alternative explanation, one less comfortable from the standpoint of incumbent firms, is that incumbents face difficulty in responding to major changes in their environments effectively, as "they are stuck in the modes of thinking and working that brought (them) success in the past" (Sull, 1999). It is easy to see why this could be the case. The sharing economy presents a particular sort of challenge to incumbents: responding to it demands new business models. Creating a new business model is a very tall order, forcing firms to develop new architectural knowledge (Gans, 2016).

The responsive actions incumbents haven taken are revealing in themselves. Nearly four-fifths of all actions, and 58\% of those categorized as "innovation," involved a relationship between the incumbent and a sharing economy company. These results indicate that incumbents tend not to act on their own, especially when they are engaged in innovation. It may be that incumbents see the sharing economy not just as a source of disruptive challenges but also as a low-risk opportunity to test new ideas developed by others.

Most of these relationships were non-strategic or even short-term. In many cases, incumbents partnered with sharing economy firms for marketing campaigns, which is captured 
in the prevalence of marketing innovation (27\%) among the four innovation categories. Perhaps incumbents see the sharing economy less as a threat than a marketing vehicle, especially in the case of sharing economy companies that operate in a different industry. For instance, incumbents have used Skillshare to offer classes about topics and skills related to their products. Some have partnered with successful sharing economy platforms such as Uber, Airbnb, and Lyft to offer short-term promotions (e.g., MasterCard partnered with Uber to provide customers in select cities a special deal on Valentine's Day 2014).

Having said that, incumbents in 42 cases did establish strategic or potentially strategic relationships with sharing economy platforms. Some of them are clearly using these relationships to take a more open and systemic approach to innovation by considering new ways to create and deliver value, as well as recognizing the importance of such interactions to their innovation capacity. These companies seem to reflect the notion that innovation does not take place in isolation and that it may involve producing new knowledge as much as combining existing knowledge from disparate sources in new ways (Edquist, 2006).

Titan Bank offers an example of the latter approach. In 2013, it partnered with Lending Club to offer personal loans to customers through Lending Club's P2P platform. As Titan Bank Director Jonathan Morris explained, "lending Club brings a low cost operating model to consumer lending. Banks, on the other hand, have a low cost of funds and deep roots in local communities. Our alliance with Lending Club truly combines the best of both worlds to bring down the cost of credit for our customers. This is the future of bank lending" (LendingClub, 2013). Ford Motor Company Executive Chairman William Clay Ford Jr. echoed that sentiment in describing his firm's collaboration with the car-sharing service Zipcar in 2011: "We are looking at the future of transportation more holistically. We shouldn't be threatened by these different business models. We should embrace them" (Vlsasic, 2011).

A bank pairing with a lending platform makes obvious sense, as does a car manufacturer with a car-sharing service. But incumbents and new entrants have also engaged in cross-sectoral collaboration. An example is Patagonia's partnership with eBay and its investment in Yerdle. The clothing company views these platforms as tools for advancing its sustainability goals in ways beyond its own capabilities (Schwartz, 2011).

The existing literature supports investment in sharing economy platforms (21 actions) as a reasonable response to the growth of the sharing economy in general (Belk, 2014; King \& Baatartogtokh, 2015; PwC, 2015b), especially in cases when incumbents face substantial threats (Habtay \& Holmén, 2014). On a few occasions, investment seemed to reflect a financial 
interest in the sharing economy (e.g., Google invested \$125 million in Lending Club). But, in other cases, investment reflects companies' acknowledgment that their size and culture limit their ability to take risks. Investments allow them to have small startups take those risks on their behalf (Stephany, 2015).

Turning to Pisano's innovation continuum, we arrive at one of the study's most interesting findings. More than $90 \%$ of innovations are routine, suggesting that the impact of the sharing economy on innovation within incumbent firms is limited, mostly resulting in incremental improvements to their business models and technical capabilities. This finding could be an indication of caution, as incumbents assess the actual threat level of the sharing economy. Such caution may be deliberate (i.e., even the companies that acknowledge the opportunities in the sharing economy are not sure about the impact of this trend). Or, in a sense, it may be coerced, reflecting the difficulty of responding to major changes in the business environment (Sull, 1999). Playing it safe could turn out to be a risky move for incumbents if predictions prove true of a radical shift in which "peer-to-peer exchange becomes increasingly prevalent, and the 'crowd' replaces the corporation at the center of capitalism," (Sundararajan, 2016, p. 2). However, as Pisano notes, while routine innovation has a bad reputation, it is a far greater source of profits than other types of innovation, so it may not be such a poor choice after all.

It is worth noting that even when incumbents launch disruptive innovations, they do so by embracing the new entrants' innovation while continuing with their traditional ways of doing business, rather than moving away from their current business model. This strategy could be justified by lessons from the Internet era, in which new ways of doing business often changed old ones, but did not displace them (The Economist, 2013).

In all of these cases the new sharing component is not crucial to the core business of the incumbent. For instance, Volkswagen and BMW have launched car-sharing programs, neither of which can even be found on their financial reports (Volkswagen, 2015). Brico Dépôt offers machinery for rent, but it mostly still creates and delivers value in a traditional way. In sum, even companies at the high end of the innovation continuum are cautious, preferring small steps toward sharing economy-inspired innovation.

This study also shows that various markets and industries respond differently to innovation pressures (Hagel et al., 2015). Consider the auto/transportation and hospitality industries. While both have seen growing sharing economy activity ( $\mathrm{PwC}, 2014)$, and incumbents face increasing competition from the likes of Airbnb, Uber, and Zipcar, this study 
reveals different, industry-dependent responses. The hospitality and auto/transportation industries show the same level of activity (ten innovation actions each). However, the latter is more innovative, with five innovation actions categorized as disruptive, while all ten hospitality industry ones are categorized as routine. These differences may reflect varying circumstances and cultures. In the hospitality industry, executives seem to downplay the impact of the sharing economy on business, at least publicly (Carr, 2014; O'Connell, 2015; PwC, 2015b), whereas auto executives acknowledge its impact on their businesses more readily (LeBeau, 2015; PwC, 2015b).

The geographic spread of both innovative and non-innovative actions suggests that the U.S. is far ahead of the other countries in question, with a share of $79 \%$ and $69 \%$ of these actions, respectively. This dominance is not surprising, given the prevalence of sharing economy activity in the U.S. and its role as one of the main engines of innovation worldwide. However, it is somewhat surprising to see that the most innovative work actually takes place in Europe, specifically in Germany. While the study identified only a few cases of disruptive innovation, the fact that five out of seven of them took place in Europe may indicate a greater openness of incumbents operating there towards taking bolder steps to adapt to a new business landscape. It is also yet to be seen how the geographical spread may change if the demand for sharing economy platforms in developing countries grows and becomes more substantial.

\section{Conclusion}

While the sharing economy could still be considered in its infancy, all indications are that it is not a fad but a robust trend that is here to stay. However, it might be too early to assume that it is "shaking up incumbent categories" (PwC, 2015b). Incumbents' responses suggest they perceive it as a mild threat, as only a small number of them were found to respond to the sharing economy actively - and among those that do, less than one-half innovate. Even then, their innovations are routine. They may be cautious and uncertain about the value of sharing economy-based concepts and models. More prosaically, it could also be the case that "adopting a new business practice or developing a new product is not so simple" (Hagel et al., 2015).

This caution is reflected in the collaborative approach many incumbents take with respect to innovation. Importantly, though, the 187 incumbent actions identified demonstrate an understanding on the part of some incumbent firms that they cannot ignore the value customers gain from sharing platforms. At least some incumbents are open to addressing innovation through a systemic and open lens, acknowledging that companies do not innovate 
in isolation (Dahlander \& Gann, 2010; Edquist, 2006), along with the shift from knowledge stocks to knowledge flows (Hagel \& Brown, 2011). These understandings are also apparent in the collaborative approach taken by many incumbents to explore these new ways offered by sharing economy platforms to create and deliver value.

The responses of incumbent companies to the sharing economy may evolve along with the sharing economy itself. More research will have to be done in order to understand comprehensively incumbents' reactions to the threats and opportunities the sharing economy presents. While this study suggests that the response so far has been mild and limited in scope and spatial extent, this situation may change if companies start recognizing that the sharing is changing the rules of the game.

\section{References}

Acquier, A., Daudigeos, T., \& Pinkse, J. (2017). Promises and paradoxes of the sharing economy: An organizing framework. Technological Forecasting and Social Change, 125, $1-10$.

Al-Saleh, Y. (2010). Systems of innovation as a conceptual framework for studying the emergence of national renewable energy industries. World Journal of Science, Technology and Sustainable Development, 7(4).

Amabile, T. M. (1988). A Model Of Creativity And Innovation In Organizations. Research in Organizational Behavior, 10, 123-167.

Bagchi, S. (2018). A Tale of Two Cities: An Examination of Medallion Prices in New York and Chicago. Review of Industrial Organization, 53(2), 295-319.

Belk, R. (2014). You are what you can access: Sharing and collaborative consumption online. Journal of Business Research, 67(8), 1595-1600.

Black, J., Hashimzade, N., \& Myles, G. D. (2009). A dictionary of economics. Oxford University Press.

Boekema, F. K., Morgan, K., Bakkers, S., \& Rutten R. (2000). Knowledge, Innovation and Economic Growth: The Theory and Practice of Learning Regions. Edward Elgar.

Botsman, R. (2014). Collaborative Finance: By the People, For the People. Collaborative Consumption. http://bit.ly/logd24R

Carlsson, B., \& Stankiewicz, R. (1991). On the nature, function and composition of technological systems. Journal of Evolutionary Economics, 1(2), 93-118.

Carr, A. (2014). What Hotel Operators Really Think Of Airbnb. Fast Company. http://bit.ly/1 mjinwF 
Cervero, R., Golub, A., \& Nee, B. (2007). San Francisco City CarShare: Longer-Term Travel-Demand and Car Ownership Impacts. http://bit.ly/1s9dcF9

Charitou, C. D., \& Markides, C. C. (2003). Responses to Disruptive Strategic Innovation. MIT Sloan Management Review.

Chase, R. (2015). Peers Inc: How People and Platforms Are Inventing the Collaborative Economy and Reinventing Capitalism. In PublicAffairs.

Chesbrough, Henry. (2006). Open Innovation: A New Paradigm for Understanding Industrial Innovation. In H. Chesbrough, W. Vanhaverbeke, \& J. West (Eds.), Open Innovation: Researching a New Paradigm (pp. 1-12). Oxford University Press.

Christensen, C. M. (1997). The Innovator's Dilemma: When New Technologies Cause Great Firms to Fail. Harvard Business School Press.

Christensen, C. M., \& Raynor, M. E. (2003). The Innovator's Solution: Creating and Sustaining Successful Growth. Harvard Business School Press.

Christensen, C. M., Raynor, M. E., \& McDonald, R. (2015, December). What Is Disruptive Innovation? Harvard Business Review. http://bit.ly/1HT2VUc

Ciulli, F., \& Kolk, A. (2019). Incumbents and business model innovation for the sharing economy: Implications for sustainability. Journal of Cleaner Production, 214, 995-1010.

Dahlander, L., \& Gann, D. M. (2010). How open is innovation? Research Policy, 39(6), 699709.

Dogru, T., Mody, M., \& Suess, C. (2019). Adding evidence to the debate: Quantifying Airbnb's disruptive impact on ten key hotel markets. Tourism Management, 72, 27-38.

Downes, L., \& Nunes, P. (2013). Big-Bang Disruption. Harvard Business Review, March 2013. https://hbr.org/2013/03/big-bang-disruption/

Economist. (2013). The rise of the sharing economy. The Economist. http://econ.st/2ye4752

Edquist, C. (1997). Systems of innovation approaches - their emergence and characteristics. In Systems of Innovation: Technologies, Institutions and Organizations. Pinter/Cassell .

Edquist, C. (2000). Systems of innovation approaches - Their emergence and characteristics. In C. Edquist \& M. McKelvey (Eds.), Systems of innovation: Growth, competitiveness and employment (p. 38). Edward Elgar Publishing.

Edquist, C. (2006). Systems of Innovation: Perspectives and Challenges. In R. R. Nelson, D. C. Mowery, \& J. Fagerberg (Eds.), The Oxford Handbook of Innovation (pp. 181-208). Oxford University Press.

Frenken, K. (2017). Sustainability perspectives on the sharing economy. Environmental Innovation and Societal Transitions, 23, 1-2.

Frenken, K., Meelen, T., Arets, M., \& van de Glind, P. (2015). Smarter regulation for the sharing economy. The Guardian. http://bit.ly/1 KjaDql 
Frenken, K., \& Schor, J. (2017). Putting the sharing economy into perspective. Environmental Innovation and Societal Transitions, 23, 3-10.

Gans, J. (2016). The Disruption Dilemma. MIT Press.

Garcia, R., \& Cantalone, R. (2002). A critical look at technological innovation typology and innovativeness terminology: a literature review. Journal of Product Innovation Management, 19(2), 110-132.

Gassmann, O., Enkel, E., \& Chesbrough, H. (2010). The future of open innovation. $R \& D$ Management, 40(3), 213-221.

Gorbis, M. (2013). The Nature of the Future: Dispatches from the Socialstructed World. Simon and Schuster.

Gunday, G., Ulusoy, G., Kilic, K., \& Alpkan, L. (2011). Effects of innovation types on firm performance. International Journal of Production Economics, 133(2), 662-676.

Habtay, S. R., \& Holmén, M. (2014). Incumbents' responses to disruptive business model innovation: the moderating role of technology vs. market-driven innovation. International Journal of Entrepreneurship and Innovation Management, 18(4), 289.

Hagel, J., \& Brown, J. S. (2011). Creation Nets: Harnessing The Potential Of Open Innovation. Journal of Service Science (JSS), 1(2), 27.

Hagel, J., Brown, J. S., Wooll, M., \& de Maar, A. (2015). Patterns of Disruption: Anticipating the Disruptive Strategy of Market Entrants. http://bit.ly/1XEVcjW

Haywood, J., Mayock, P., Freitag, J., Owoo, K. A., \& Florilla, B. (2017). Airbnb \& Hotel Performance. http://bit.ly/2kQulFJ

Henderson, R. M., \& Clark, K. B. (1990). Architectural Innovation: The Reconfiguration of Existing Product Technologies and The Failure of Established Firms. Administrative Science Quarterly, 35(1), 9-30.

Jehlička, P., \& Daněk, P. (2017). Rendering the Actually Existing Sharing Economy Visible: Home-Grown Food and the Pleasure of Sharing. Sociologia Ruralis, 57(3), 274-296.

Johnson, B., \& Lehmann, M. (2006). Sustainability and Cities as Systems of Innovation. In DRUID Working Paper No. 06-17.

King, A. A., \& Baatartogtokh, B. (2015). How Useful Is the Theory of Disruptive Innovation? MIT Sloan Management Review, Fall 2015.

Lacy, S. (2015). Let's face it: Uber IS the sharing economy. Pando. http://bit.ly/1ZfpQwT Laurell, C., \& Sandström, C. (2016). Analysing Uber In Social Media - Disruptive Technology Or Institutional Disruption? International Journal of Innovation Management, 20(05).

LeBeau, P. (2015). Ford jumps into car-sharing business. CNBC. http://cnb.cx/2xRsOmL 
LendingClub. (2013). Community Banks Join the Lending Club Platform. http://bit.ly/1Y4xkVh

Lowes, R., Woodman, B., \& Fitch-Roy, O. (2016). Defining Incumbency: Considering the UK Heat Sector.

Lundvall, B.-Å. (1985). Product Innovation and User-Producer Interaction. Aalborg University Press.

Mabert, V. A., Soni, A., \& Venkataramanan, M. A. (2003). The impact of organization size on enterprise resource planning (ERP) implementations in the US manufacturing sector. Omega, 31(3), 235-246.

Mair, J., \& Reischauer, G. (2017). Capturing the dynamics of the sharing economy: Institutional research on the plural forms and practices of sharing economy organizations. Technological Forecasting and Social Change, 125, 11-20.

Martin, C. J. (2016). The sharing economy: A pathway to sustainability or a nightmarish form of neoliberal capitalism? Ecological Economics, 121, 149-159.

Martin, E., Shaheen, S. A., \& Lidicker, J. (2010). The Impact of Carsharing on Household Vehicle Holdings. Transportation Research Record: Journal of the Transportation Research Board, 2143(1), 150-158.

Matzler, K., Veider, V., \& Kathan, W. (2015). Adapting to the Sharing Economy. MIT Sloan Management Review. http://bit.ly/1TKqZMP

McKinnon, C. (2015). Open innovation is good for business | Opensource.com. Opensource.Com. http://red.ht/1X1jhkb

Moazed, A., \& Johnson, N. L. (2016). Why Clayton Christensen Is Wrong About Uber And Disruptive Innovation. Techcrunch. http://tcrn.ch/1T3aOe1

Murillo, D., Buckland, H., \& Val, E. (2017). When the sharing economy becomes neoliberalism on steroids: Unravelling the controversies. Technological Forecasting and Social Change, 125, 66-76.

O’Connell, J. (2015). Q\&A: Marriott CEO Arne Sorenson. The Washington Post. http://wapo.st/1XGNOgT

OECD. (2005). Oslo Manual: Proposed Guidelines for Collecting and Interpreting Technological Innovation Data. OECD Publishing. http://bit.ly/1sVqVzp

Olson, M., \& Kemp, S. (2015). Sharing Economy: An In-Depth Look At Its Evolution and Trajectory Across Industries - Collaborative Economy. In Piper Jaffray. http://bit.ly/113F8Gi

Owyang, J. (2015a). Get Data and Stats for your Collaborative Economy Research. WebStrategist.Com. http://bit.ly/1UHSpj8

Owyang, J. (2015b). Report: The New Rules of the Collaborative Economy, 2015 Data on the 
Rise of Sharing. Web Strategy by Jeremiah Owyang. http://bit.ly/1jK2EYZ

Owyang, J., \& Samuel, A. (2015). The New Rules of the Collaborative Economy. http://bit.ly/1PXcCTr

Pisano, G. P. (2015). You Need an Innovation Strategy. Harvard Business Review, 93, no. 6(June 2015), 44-54. https://hbr.org/2015/06/you-need-an-innovation-strategy

PwC. (2014). The Sharing Economy: How Will It Disrupt Your Business? http://bit.ly/1ZINhF2

PwC. (2015a). 18th Annual Global CEO Survey. https://pwc.to/1Ms8gyP

PwC. (2015b). The Sharing Economy: Consumer Intelligence Series. http://pwc.to/1ZuWVGV

Raynor, M. E. (2013). Introducing perspectives on innovation. Deloitte University Press. http://dupress.com/articles/introducing-on-innovation/

Roh, T. H. (2016). The Sharing Economy: Business Cases of Social Enterprises Using Collaborative Networks. Procedia Computer Science, 91, 502-511.

Roma, P., Panniello, U., \& Lo Nigro, G. (2019). Sharing economy and incumbents' pricing strategy: The impact of Airbnb on the hospitality industry. International Journal of Production Economics, 214, 17-29.

Sacks, D. (2011). The Sharing Economy. Fast Company. http://bit.ly/21W074s

Schor, J. (2014). Debating the Sharing Economy. In Great Transition Initiative. http://www.greattransition.org/publication/debating-the-sharing-economy

Schor, J., \& Attwood-Charles, W. (2017). The "sharing" economy: labor, inequality, and social connection on for-profit platforms. Sociology Compass, 11(8).

Schumpeter, J. A. (1934). The Theory of Economic Development: An Inquiry Into Profits, Capital, Credit, Interest, and the Business Cycle. Transaction Publishers.

Schwartz, A. (2011). Patagonia Invests In Yerdle Through Its Internal Venture Fund. Fast Company. http://bit.ly/1v0Ogj8

Seamans, R., \& Zhu, F. (2014). Responses to Entry in Multi-Sided Markets: The Impact of Craigslist on Local Newspapers. Management Science, 60(2), 476-493.

Stephany, A. (2015). What's a Corporate to do? 4 Strategies for Coping with Sharing Economy Disruption. Alex Stephany. http://bit.ly/2lTQq6t

Sull, D. (1999). Why Good Companies Go Bad. Harvard Business Review. http://bit.ly/1vMLOgw

Sundararajan, A. (2016). The Sharing Economy: The End of Employment and the Rise of 
Crowd-Based Capitalism. MIT Press.

Van de Ven, A. H. (1986). Central Problems in the Management of Innovation. Management Science, 32(5), 590-607.

Vlsasic, B. (2011). Ford and Zipcar Join Forces. The New York Times. http://nyti.ms/1PnCv0w

Volkswagen. (2015). VW 2014 earnings report. http://bit.ly/1Y8etIL

Wadhwa, V. (2015). What the legendary Clayton Christensen gets wrong about Uber, Tesla and disruptive innovation. In The Washington Post. http://wapo.st/11FqBBB

West, J., \& Bogers, M. (2013). Leveraging External Sources of Innovation: A Review of Research on Open Innovation.

Zhang, C., Kettinger, W., Kolte, P., \& Yoo, S. (2018). Established Companies' Strategic Responses to Sharing Economy Threats. MIS Quarterly Executive, 17(1). 